\title{
Cyborg Technology: A Quiet Revolution
}

\author{
Jaya Pradha Dhandapani
}

\begin{abstract}
Cyborg technology is one among the new scientific achievements takes humankind to next level. Cyborgs are machine that has inner metallic endoskeleton and outer living tissue. The history of cyborg technology dates back to $1960 .{ }^{1}$ Two NASA scientists named Nathan Kline and Manfred Clynes were the first to coin the term Cyborg. ${ }^{2}$ Their vision is to enhance mankind survival in an extraterrestrial environment. Cyborg has been divided into two types such as convenient cyborg and conditional cyborg. ${ }^{2}$ The main difference between the cyborg and robot is, a cyborg is a part of living beings but robot is a nonliving automated machine. The incorporation of cyborg technology in humans includes hearing color, the luke arm, visualizing light, hand gripping and artificial eyes. Example of such technology was first witnessed in the movie Star Wars and currently it is used as a prosthetic for humans in order to create the touch sense and to help in their normal day-to-day life. ${ }^{3}$ Scope in cyborg technological development such as computer-controlled smart limbs, nanomedicine, uploading the brain and invisibility technology. ${ }^{4}$ It has both advantages and disadvantages but hope in future this will bring a quiet revolution in technology advancement and upgrade human to next level. ${ }^{5}$

Keywords: Cyborg, Human, Science and technology.

Pondicherry Journal of Nursing (2019): 10.5005/jp-journals-10084-12133
\end{abstract}

\section{INTRODUCTION}

Science and technological advancement has made humankind into next level. One among the new scientific achievements is the cyborg technology. The word cyborg stands as a combination of cybernetics and organism. ${ }^{6}$ In the year 1960, the name cyborg was given by Manfred Clynes. He is the one who identified the importance of artificially enhanced biological functions for human being. ${ }^{1}$ These cyborgs are portrayed as half-man and half-machine beings that are both robotic and bionic implants. ${ }^{6}$

Cyborgs are machine that has inner metallic endoskeleton and outer living tissue. A cyborg is a human being who is physically in connection with the technology. ${ }^{7}$ Neil Harbisson is a blind artist who visualizes the world by means of an electronic implant in his head. ${ }^{8}$ This technology increases the strength and sensation which enables people to overcome disability. ${ }^{7}$ Cyborg technology helps in replacement of missing limbs, injured organs, and decreased sense. ${ }^{3}$

\section{History of Cyborg}

The history of cyborg technology dates back to 1960. Two NASA scientists named Nathan Kline and Manfred Clynes were the first to coin the term cyborg. Their vision is to enhance mankind survival in an extraterrestrial environment. ${ }^{2}$ The world's first international organization was launched in 2010 as Cyborg Foundation in order to help humans change over to cyborgs. In the year 1908, Jean de La Hire announced the novel L'Homme qui peut vivre dans l'eau (the man who can live in the water). ${ }^{9}$

\section{Cyborg Foundation}

People around the world show more interest towards becoming cyborg. That initiated Neil Harbisson and Moon Ribas to start the Cyborg Foundation. ${ }^{5}$ The vision of the foundation is to improve
Department of Community Health Nursing, Kasturba Gandhi Nursing College, Sri Balaji Vidyapeeth, Puducherry, India

Corresponding Author: Jaya Pradha Dhandapani, Department of Community Health Nursing, Kasturba Gandhi Nursing College, Sri Balaji Vidyapeeth, Puducherry, India, Phone: +91 7639126403, e-mail: J.pradhaa17@gmail.com

How to cite this article: Dhandapani JP. Cyborg Technology: A Quiet Revolution. Pon J Nurs 2019;12(4):96-99.

Source of support: Nil

Conflict of interest: None

human senses and abilities by means of cybernetic extension to the body. This foundation was awarded Cre@tic Award by Technocampus Mataro in the year of $2010 .^{5}$

\section{Meaning}

Cyborg is a combined model between human and machine that differs from a robot. It was aimed at overcoming and recovering from physical and mental constraints. ${ }^{10}$

\section{Types of Cyborg}

Cyborg has been divided into two types:

- Convenient cyborg

- Conditional cyborg

\section{Convenient Cyborg}

This type is used as per the human conveniences for their fancy needed. Here human can alter their body parts according to their wish by provision of exoskeleton. ${ }^{2}$

(c) The Author(s). 2019 Open Access This article is distributed under the terms of the Creative Commons Attribution 4.0 International License (https://creativecommons. org/licenses/by-nc/4.0/), which permits unrestricted use, distribution, and non-commercial reproduction in any medium, provided you give appropriate credit to the original author(s) and the source, provide a link to the Creative Commons license, and indicate if changes were made. The Creative Commons Public Domain Dedication waiver (http://creativecommons.org/publicdomain/zero/1.0/) applies to the data made available in this article, unless otherwise stated. 


\section{Conditional Cyborg}

This aims at the replacement of any designed or injured body parts with bionic implants that revert back to the normal functional life of human being. ${ }^{2}$

\section{Difference between Cyborg and Robot}

\begin{tabular}{|c|c|}
\hline Cyborg & Robot \\
\hline $\begin{array}{l}\text { A cyborg is a combination } \\
\text { of machine and organism. It } \\
\text { is a part of living beings. }\end{array}$ & $\begin{array}{l}\text { A robot is a nonliving } \\
\text { automated machine. }\end{array}$ \\
\hline $\begin{array}{l}\text { - It is significantly } \\
\text { complicated one." }\end{array}$ & $\begin{array}{l}\text { Robots can be both } \\
\text { complex and simple. }{ }^{11}\end{array}$ \\
\hline $\begin{array}{l}\text { Cyborgs are not only } \\
\text { applied to human being, } \\
\text { but also to other living } \\
\text { organisms such as animals } \\
\text { and birds. }\end{array}$ & $\begin{array}{l}\text { A robot is an automated } \\
\text { machine that has advanced } \\
\text { technologies which } \\
\text { require minimal human } \\
\text { interactions. }{ }^{12}\end{array}$ \\
\hline $\begin{array}{l}\text { - Cyborgs are half- } \\
\text { mechanical and half- } \\
\text { biological. }{ }^{1}\end{array}$ & $\begin{array}{l}\text { A robot need not replicate } \\
\text { the human beings. }\end{array}$ \\
\hline
\end{tabular}

\section{Incorporating Human in Cyborg TECHNOLOGY}

\section{Hearing Color}

Neil Harbisson was born color-blind; later, in 2004, he implanted an electronic antenna in the back of his skull that changes frequencies of light into vibration. This vibration was recognized as sound by brain paving the way for him to hear color. ${ }^{3}$

\section{Luke Arm}

This was first seen in the movie Star Wars. Presently, it is used as a prosthetic for humans in order to create the touch sense and to help in their normal day-to-day life. The technology used here will receive electronic sensation signals from muscles and convert it into physical movement. ${ }^{13}$

\section{Visualizing Light}

Jan's Neumann was blind at the age of 20; later, he was given an opportunity to use this cyborg technology. A television camera is attached to his brain channeling the damaged eyes which allowed him to watch Christmas light that year. ${ }^{14}$

Neil Harbisson is a blind artist who visualizes the world by means of an electronic implant in his head. This technology increases the strength and sensation which enables people to overcome disability. Cyborg technology helps in the replacement of missing limbs, injured organs, and decreased sense.

Zac Vawter met up with an accident and lost his leg. This technology paved the way for him to first use a mind-controlled bionic leg which translates brain signals into movement. ${ }^{13}$

\section{Hand Gripping}

The Bebionic Company first introduced an intricate prosthetic hand design in 2017. This technology used specialized motor function that controls joint and digit independently. It has 14 pre-programmed grip functions which can hold an egg and manage up to 99 pounds of weight. ${ }^{3}$

\section{Artificial Eyes}

Rob Spence, a film director, used an artificial eye to his missing right eye which has a wirelessly transmitting video camera. It has a video recording capacity of up to 30 minutes with full battery (Fig. 1). ${ }^{9}$

\section{Scope in Cyborg Technological DeVelopment}

\section{Neural Implants}

It will be a dream come true if we connect our mind with computer, but the technological advancement makes it reality. ${ }^{15}$ Today's neural implants are cochlear implants to retain hearing and retinal implants to repair failing vision. These basic neural implants have advanced features and functions. ${ }^{4}$

\section{Computer-controlled Smart Limbs}

Touch Bionics, a prosthetic tech company, has launched a hand which was controlled by a smartphone app. Not everyone considers adding a limb. Many believe in improving our own limbs with smart, computer-controlled prosthetics in near future. ${ }^{8}$

Current prosthetics are of tremendous help to those who have lost limbs, and these prosthetics are getting smarter every day. For example, "Touch Bionics" I-limb, prosthetic hand has a characteristics of rotating thumb, five individual potential fingers, a rotatable wrist, and aluminum chassis. ${ }^{9}$

\section{Nanomedicine}

Nanotechnology, a medical miracle, delivers tiny "smart" particles wherever needed in the body. One experimental lung cancer treatment has the patient inhale nanoparticles by aerosol; the particles settle in diseased areas of the lungs. An external magnet superheats the particles, which kills diseased cells. ${ }^{4}$

\section{Uploading the Brain}

Ray Kurzweil believes that by 2040 to 2045 , any human will be able to upload his or her consciousness into a computer. ${ }^{15}$ One Russian billionaire has revealed that he plans to process his own brain, that becoming immortal, no later than the year of $2045 .{ }^{10}$ Dmitry Itskov, 32 , believes that cyborg technology will let him live lasting for unknown in a hologram body. Using the neural interface, human beings can able to operate various bodies from distance. ${ }^{16}$

\section{Invisibility Technology}

Technology experts say a real-life Harry Potter invisibility cloak is arriving soon. Though it is apart from optimal operation, the researchers have been working already on invisibility cloaks. Most recently, engineers have encircled an object with small antennas that collectively radiated an EM field, cancelling out visible light waves. $^{14}$

\section{Advantages of Cyborg}

- It extends the duration of life.

- It can help lead normal human life. ${ }^{5}$

- The quality of life has improved.

- It can be useful for various professions.

- The cyborg can do the human daily routine work.

- Cyborg can give artificial parts of human body. ${ }^{17}$ 

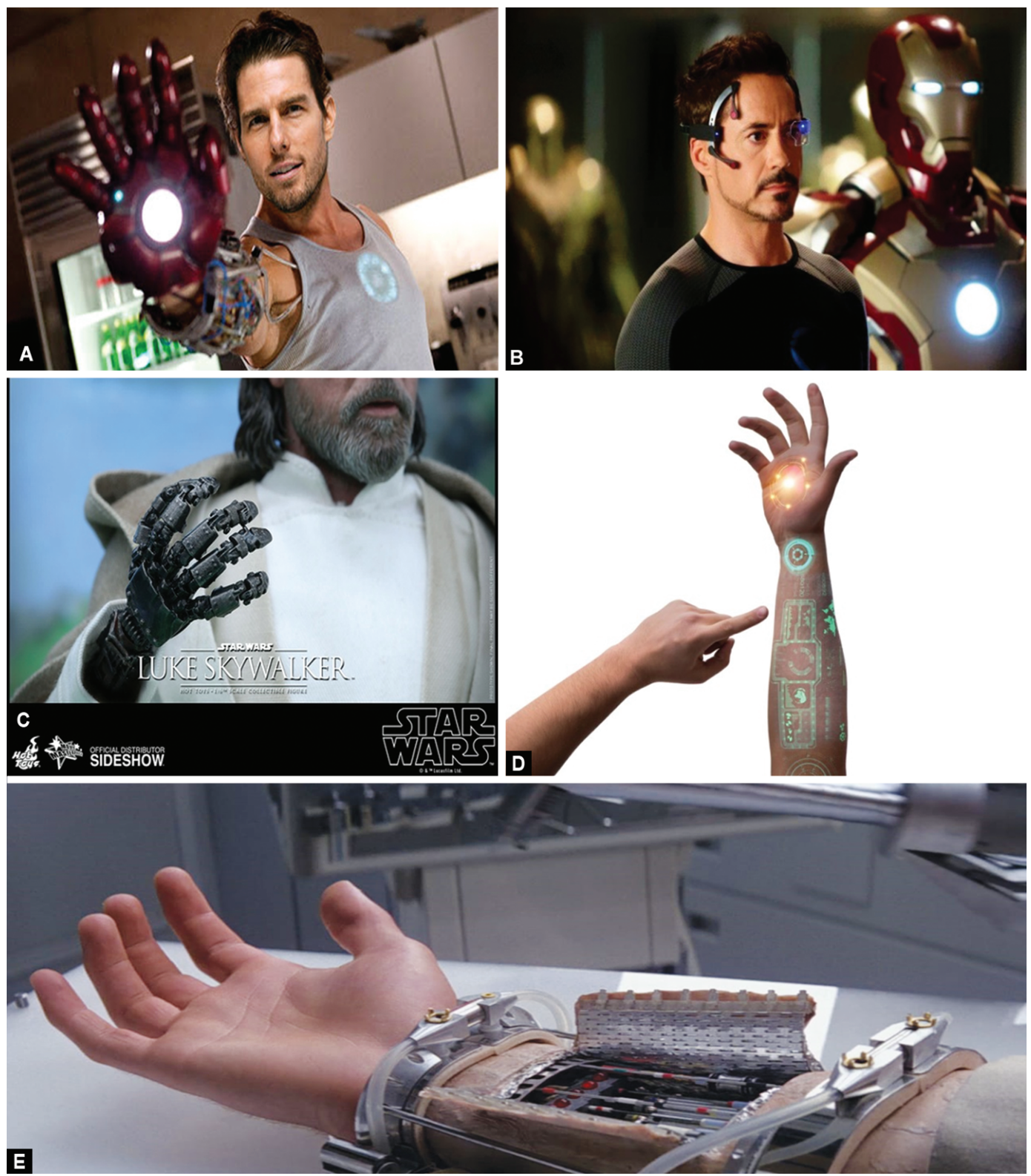

Figs $1 \mathrm{~A}$ to $\mathrm{E}$ : Prosthetic hand grip

\section{Disadvantages of Cyborg}

- More training is needed.

- It is more expensive.

- Psychological problems may occur.

- They have their physical limitations.

- It does not heal body damages in normal way.

- It always requires proper maintenance. ${ }^{18}$

\section{CONCLUSION}

An astonishing amount of cybernetic technology already exists to help people with disabilities and to improve the basic functions of their bodies. ${ }^{19}$ While these tools are reserved for those with amputations or other disabilities, it does seem that commercially available bionic enhancements are not that far away. We can be on the lookout for options that could enhance our human experience. ${ }^{1}$

\section{References}

1. A cyborg manifesto: science technology and socialist-feminism in the late 20th century 2014 Feb 14th at the wayback machine by donna haraway.

2. Kline Nathans, Manfred E. Cylnes cyborg and space 'astronautics, 1960 sep, pp. 26-27 and 74-75; reprinted in gray,mentor, and Figueroasarriers, ed., The cyborg handbook, newyork; routledge, 1995. pp. 29-34.

3. https://www.nationalgeographic.com/magazine/2017/04/evolutiongenetics-medicine-brain-technology-cyborg/.

4. http://s.telegraph.co.uk/graphics/projects/the-future-is-android/.

5. Garcia FC. Nace una fundacion dedicadada a convertir humanos en cyborgs; la vanguardia, 1 March 2011.

6. Sofoulis Zoe. Cyber quake: caraways manifesto in tofts, Darren, an intellectual history, Sydney. publication, 2002. pp. 84-103.

7. https://gizmodo.com/how-close-are-we-to-building-a-full-fledgedcyborg-1443146375. 
8. http://www.dailymail.co.uk/sciencetech/article-2547086/WantCYBORG-The-technologies-mega-zoom-vision-ability-pick-car.html.

9. https://futurism.com/six-of-todays-most-advanced-real-lifecyborgs/.

10. Space and cyborg, in astronautics in 1960 sept by Manfred E Clynes and American scientist and researcher Nathan.s Kline.

11. Cyborgs vl.o by marcon chackon.

12. Clynes ME, Kline NS. Cyborgs and space. Astronautics. Orangeburg, NY: Rockland State Hospital; 1960. pp. 26-27.

13. Harawy DJ. A cyborg manifesto in harway. Simians, Cyborgs and Women, Reinvention of nature, Newyork: Routledge; 1991. pp. 149-181.
14. https://www.cyborartsweb.org/space/cyborg/advent.html.

15. https://www.theguardian.com/technology/2017/feb/15/elon-muskcyborgs-robots-artificial-intelligence-is-he-right.

16. Robert R. Powel Future Cyborgs; Human machine interface for vitrual Realityy Applications, major, USAF April 2007, department.

17. Joseph C. The techno-human shell-a jump in the evolutionary gap. Sunbury Press; 2012. ISBN 978-1-62006-165-7.

18. Halacy DS. Cyborg; evolution of the superman. Newyork: Row Publishers; 1965. p. 7.

19. Cyborg; digital destiny and human possibility in the age of the wearable computers, retrieved 4 July 2013 